\title{
Fiscal Sustainability in Remittance-Dependent Economies
}

\author{
Yasser Abdih, Ralph Chami, Michael Gapen, \\ and Amine Mati
}




\title{
IMF Working Paper
}

Middle East and Central Asia Department

Fiscal Sustainability in Remittance-Dependent Economies

Prepared by Yasser Abdih, Ralph Chami, Michael Gapen, and Amine Mati ${ }^{1}$

September 2009

\begin{abstract}
This Working Paper should not be reported as representing the views of the IMF. The views expressed in this Working Paper are those of the author(s) and do not necessarily represent those of the IMF or IMF policy. Working Papers describe research in progress by the author(s) and are published to elicit comments and to further debate.
\end{abstract}

We investigate the impact of remittances on public debt sustainability and detail how the traditional debt-to-GDP ratio can be modified to create a more accurate representation of debt sustainability for a country that receives significant remittance inflows. The main result is that inclusion of remittances into the traditional debt sustainability analysis alters the amount of fiscal adjustment required to place debt on a sustainable path. While preliminary, these results are indicative of how a one-size-fits-all stability analysis may be inappropriate when evaluating the stance of fiscal policy for countries with different balance of payments characteristics.

JEL Classification Numbers:F22, F24, F41, H30, H62, H63, H68

Keywords: Remittances, fiscal sustainability, remittance-dependent economies Author's E-Mail Address:yabdih@imf.org, rchami@imf.org, michael.t.gapen@,fdr.gov; and amati@imf.org

\footnotetext{
${ }^{1}$ The paper has benefited from useful comments and discussions with Allan Brunner, Domenico Fanizza, Harald Finger, Giovanni Ganelli, Dalia Hakura, Pablo Lopez-Murphy, Axel Schimmelpfennig, and Carlo Sdralevich. The views expressed are solely those of the authors and should not be reported as representing the views of the Board of Governors of the Federal Reserve System or of any other person associated with the Federal Reserve System.
} 


\section{Contents}

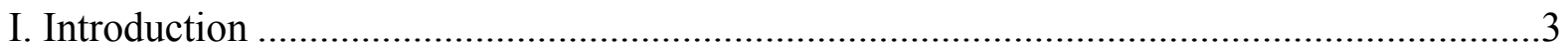

II. Implication of Remittances for Public Debt Sustainability ............................................5

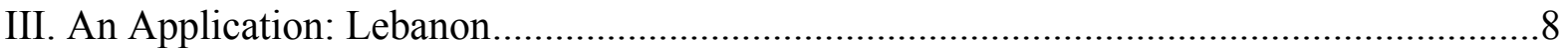

A. Stabilizing the Debt at Current Levels ........................................................... 10

B. Targeting a Lower Debt Level ................................................................. 10

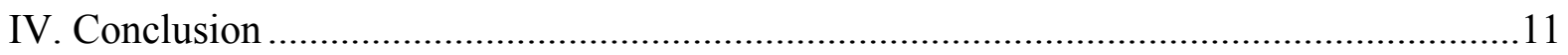

I. Traditional Model of Debt Sustainability .................................................................17

A. The law of motion of the government debt-to-GDP ratio................................... 17

B. The primary surplus-to-GDP ratio that stabilizes the debt-to-GDP ratio.................18

C. The primary surplus-to-GDP ratio that reduces debt-to-GDP to a given target......18

II. Debt Sustainability in the Presence of Remittances...................................................19

A. The law of motion of the government debt-to-GDP plus remittances ratio.............20

B. The primary surplus-to-GDP ratio that stabilizes debt-to-GDP plus remittances...21

C. The primary surplus-to-GDP ratio that reduces debt-to-GDP plus remittances to a

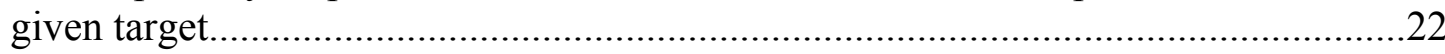

Tables

1. Debt Dynamics and Primary Surpluses that Stabilize the Debt Ratio for Lebanon ............15

2. Primary Surplus Required to Reduce the Debt Ratio to a Given Target ........................... 16

Figures

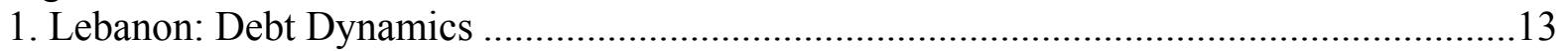

2. Lebanon: Primary Surpluses that Stabilize the Debt Ratio..............................................14

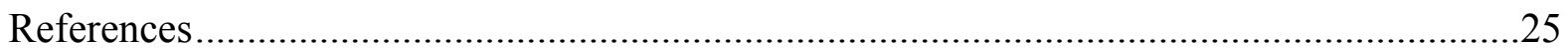




\section{INTRODUCTION}

Inflows of workers' remittances have been growing rapidly in many developing countries at least since the early 1990s. With recent estimates putting remittances at $\$ 135$ billion, they now rival and even exceed other types of balance of payments inflows that have traditionally received much more attention. Since 1998, these private income transfers - at least those flowing through official channels - have been second only to FDI flows, but several times larger than remaining private capital inflows and official aid (World Bank, 2006; IMF, 2005; Chami et al., 2008).

There is now a substantial literature that has documented the welfare-enhancing benefits of remittances for the recipients. For example, remittances are credited with reducing poverty, and their compensatory nature is responsible for minimizing consumption volatility of transfer recipients (Chami, Fullenkamp, and Jahjah, 2003; World Bank, 2006; IMF, 2005; among others). Researchers, however, have also recognized that these flows entail several development challenges, particularly in terms of their effect on growth (Barajas et. al. 2009, Chami et al., 2003, 2008; World Bank, 2006; IMF, 2005), and Dutch disease effect (Montiel, 2006; Acosta, Lartey and Mandelman, 2007, among others).

In contrast to the well documented impact of remittances on recipient households, the macroeconomic impact of these flows has received scant attention until recently. Chami, Cosimano, and Gapen (2006) examine the Ramsey problem in a general equilibrium framework and find that remittances also affect the setting of optimal fiscal and monetary policy in the recipient countries. In particular, the authors find that remittances, by increasing consumption, expand the revenue base, which allows the government to carry more debt or incur more expenditures.

The result that remittances have a significant effect on fiscal policy and debt sustainability may initially be surprising since governments have no direct claims on these person-toperson transfers. Nevertheless, since remittances enter the recipient economy through familial transfers they affect fiscal policy and debt sustainability indirectly through the activities of remittance-receiving households, primarily through their consumption decisions and saving patterns. In this respect remittances are different from natural resources which governments may own and from which they derive revenue, foreign and domestic public aid transfers which enter the government budget constraint directly, and private capital flows that enter directly into the production process.

Remittances affect debt sustainability through several channels:

- Higher tax base. Even if they are not taxed directly, remittance flows may indirectly increase the revenue that the government receives from consumption- and trade-based taxation since they contribute to higher consumption of domestic and imported goods. ${ }^{2}$ However, the strength of this channel is dependent on the tax structure in

\footnotetext{
${ }^{2}$ To the extent that remittances are transmitted through formal channels and hence are measurable, they can be taxed using financial transactions taxes, but governments generally avoid this type of taxation for several
} 
place in remittance-receiving countries. With approximately half of revenues in developing countries due to consumption and production taxes (Gordon and Li, 2006), the evidence suggests this channel may be particularly robust. In this case, higher remittances that lead to an increase in the tax base can also lower country risk and reduce the marginal cost of borrowing.

- $\quad$ Seigniorage. If remittances increase the domestic demand for banking sector liabilities, the demand for money will rise. ${ }^{3}$ As a result, for a given rate of inflation, the government's seigniorage revenue will tend to increase.

- Higher private savings. Remittances may lead to increased deposits in the banking system, and to the extent that the marginal propensity to consume is less than unity, remittances may increase private savings. This higher level of private saving could be channeled by the banks - through the purchases of government bonds - to support higher government debt levels.

These channels suggest that remittances can be viewed as part of the potential tax base in addition to income from production. They also suggest that, by increasing the government's potential revenue base, remittances augment the resources that a country has available to borrow or service its debt.

The main purpose of this paper is to investigate the impact of remittances on the sustainability of government debt. In particular, we examine how traditional debt sustainability analysis relating fiscal policy and the evolution of the debt-to-GDP ratio is altered in the presence of remittances. If remittances do increase the potential revenue base then a more accurate representation of debt sustainability for a country that receives significant remittance flows should employ as a base a more-aggregated measure of income than GDP. Though gross national disposable income (GNDI) is an obvious candidate, we

reasons. Such a tax may cause the transfers to migrate to informal channels, lowering welfare by increasing the costs of remitting; counter the ongoing international efforts against money laundering; and potentially reduce the overall quantity of remittances.

${ }^{3}$ This effect may be operative if the presence of remittances affects the domestic demand for money, and thus the public's demand for the liabilities of the domestic financial system. There are at least two ways in which the domestic demand for money may be affected by the presence of remittance flows. First, a larger level of remittances increases the resources (income) available to domestic households and thus increases household expenditure. The implication is that the transactions demand for money would increase in the receiving economy, especially if remittances support the consumption patterns of low-income households with high marginal propensity to consume. Second, if remittances are altruistic, the presence of remittance flows may affect the demand for money through their implications for the level of economic uncertainty faced by the recipient households. Many studies have found that the demand for domestic money decreases in response to an increase in domestic macroeconomic uncertainty (e.g., domestic uncertainty causes domestic agents to shift their assets abroad, rather than holding them in the domestic financial system). To the extent that altruistic remittances function as insurance for the recipient household, the presence of such remittances would tend to reduce the impact of aggregate uncertainty on the individuals who receive them, thus weakening its effect on their demand for money. In sum, for a given level of aggregate uncertainty, altruistic remittances would tend to increase the demand for money at any given level of income. 
believe a more narrowly constructed measure of GDP plus remittances is appropriate. We use this measure to examine debt sustainability in the case of Lebanon, a country which carries a significant debt burden and has also received a high level of remittances over time. In addition, the current financial crisis and the global slowdown in economic activity are expected to negatively affect remittance inflows in many remittance-dependent economies, including Lebanon, and therefore provide an appropriate backdrop to illustrate cross-border linkages which are essential in assessing stability.

We find that including remittances into debt sustainability analysis alters the amount of fiscal adjustment required to place debt on a sustainable path. The effect, however, is not simply a level effect and the presence of remittances does not automatically imply reduced fiscal adjustment. Indeed, we find that the important factor in evaluating the appropriate fiscal stance is the relative growth rate of remittances and GDP. All else equal, if the real growth rate of remittances exceeds the growth rate of real GDP, then less fiscal adjustment is needed relative to that suggested under traditional analysis. Conversely, if the growth rate of remittances falls below the growth rate of GDP, then additional fiscal adjustment may be required. While these results should be viewed as preliminary, we believe they are illustrative of weaknesses in a one-size-fits-all analysis of sustainability. Remittance-dependent countries like Lebanon may be better served by assessing the stance of fiscal policy and debt sustainability using several metrics, including one that accounts for the behavior of remittances.

The remainder of this paper is organized as follows. Section II examines the implications of remittances for public debt sustainability. The analysis in this section is supported by the mathematical appendix which details how the mechanics of traditional debt sustainability analysis change in the presence of remittances. Section III then applies the new methodology to the case of Lebanon while Section IV contains concluding remarks.

\section{Implication of Remittances for Public Debt Sustainability}

The traditional model of debt sustainability starts with the government budget constraint, which links fiscal deficits to the accumulation of the corresponding debt stocks over time. ${ }^{4}$ Debt levels (and fiscal deficits) are then normalized by some measure of the country's ability to service and repay its debt—with the typical choice being GDP. Debt sustainability assessments using this framework involve an understanding of the dynamic evolution of the debt-to-GDP ratio, the path of which depends critically on the relationship between the country's real GDP growth and the real interest rate on its debt. As shown in the Appendix, the traditional model of debt sustainability results in a path of the debt-to-GDP ratio of

\footnotetext{
${ }^{4}$ Here we abstract from other financing items of fiscal deficits, such as seigniorage, privatization proceeds, and the sale of government liquid assets. None of the results mentioned in the text are altered by this simplification.
} 


$$
\Delta d_{t}=\left[\frac{r_{t}-g_{t}}{1+g_{t}}\right] d_{t-1}-p s_{t},
$$

where the change in the debt-to-GDP ratio, $\Delta d$, is related to the real interest rate, $r$, the real growth rate of GDP, $g$, the debt-to-GDP ratio in the previous period, and the level of the primary surplus in percent of GDP, $p s$. Primary surpluses that keep the debt on a sustainable path increase with the real interest rate and the level of debt-to-GDP, but decrease with the real growth rate of GDP. If the real interest rate exceeds real GDP growth, then primary deficits may lead to an unsustainable explosive debt path.

However, as discussed in the previous section, the existing literature and evidence suggests that remittances can be viewed as part of the potential tax base, augmenting the available resources that a country has to service its debt. If so, then a more accurate representation of intertemporal debt sustainability for a country that receives significant remittance flows should employ as a base a more-aggregated measure of income than GDP.

One possible solution would be to use gross national disposable income (GNDI) instead of GDP when estimating the evolution of liabilities in an open-economy setting. However, while GNDI includes remittances, it also includes other flows that are not suitable for inclusion in the potential revenue base. For example, GNDI includes net factor income from non-residents and public transfers, including grants. A component of net factor income is employee compensation, which represents wages, salaries, and other benefits earned by individuals in countries other than those in which they are residents for work performed for and paid for by residents of those countries. As such, employee compensation may not represent an actual flow and may indeed be part of the tax base of another country. ${ }^{5,6} \mathrm{~A}$ second component of net factor income, public sector transfers, may be lumpy and inconsistent over time. They may also come with conditionality which may prevent their direct use for debt servicing.

For these reasons, we suggest using the more refined measure of GDP plus remittances as the base-measure for sustainability assessments. We believe this measure, rather than GDP or GNDI , best characterizes the ability of a remittance-receiving economy to service its debt. We note here, however, that the counterfactual is not true. We are not suggesting debt sustainability assessments in source countries of remittances need to be adjusted to account for outflows of private income transfers. Remittance outflows are generally a byproduct of labor supply in the production process, which is already included as part of GDP at the tax base of the source country. Consequently, GDP is a reasonable number to use for an

\footnotetext{
${ }^{5}$ Salaries of IMF and World Bank staff, for example, are recorded under employee compensation in the balance of payments for staff's country of origin. While it is true that remittance flows may be the result of wages and salaries earned abroad, we only view those resources which are actually remitted as part of the revenue base of the receiving country to support debt service costs.

${ }^{6}$ Chami et al. (2008) also show that employee compensation has different behavioral characteristics from the category workers' remittances and may therefore be capturing a different activity.
} 
indication of economy-wide resources available to meet debt obligations in the largest source countries of remittances. The argument also supports why gross remittance inflows are examined here instead of net remittance inflows.

In this context, we show in the Appendix how the traditional model of debt sustainability is modified to account for remittances. We show that the dynamic path of the debt-to-GDP plus remittances ratio will now depend on the relationship between the real interest rate on the country's debt and the real growth rate of GDP plus remittances - which is a weighted average of the real GDP growth rate and the real growth rate of remittances. ${ }^{7}$ In particular, the equivalent of equation (1) for the path of the debt-to-GDP plus remittances, $\Delta d$, becomes,

$$
\Delta d_{t}=\frac{r_{t}-\left[g_{t}+s_{t-1}\left(\rho_{t}-g_{t}\right)\right]}{1+\left[g_{t}+s_{t-1}\left(\rho_{t}-g_{t}\right)\right]} d_{t-1}-p s_{t}
$$

where $\rho$ is the real growth rate of remittances, $s$ is the share of remittances in GDP plus remittances, and the primary surplus is also a ratio to GDP plus remittances.

All else equal, an increase in the real growth rate of remittances will increase the country's capacity to repay its debt, and hence will improve debt sustainability. In some cases, provided that the real growth of remittances is large enough, the debt-to-GDP plus remittances ratio may be falling over time, even when the debt-to-GDP ratio is rising. In such cases, a remittance-dependent country that relies on the path of the debt-to-GDP ratio to evaluate sustainability may, erroneously, conclude that debt is not sustainable while in reality it may be. In addition, if the real growth rate of remittances exceeds the real growth rate of GDP, then we show formally in the Appendix that:

- the primary surplus-to-GDP ratio that stabilizes the debt-to-GDP plus remittances ratio will be less than the primary surplus-to-GDP ratio that stabilizes the debt-toGDP ratio and,

- the primary surplus-to-GDP ratio that reduces debt-to-GDP plus remittances by a given percentage over a period of $N$ years will be less than the primary surplus-toGDP ratio that reduces the debt-to-GDP ratio by the same percentage over the same period of time.

The intuition behind these results is straightforward. If the real growth rate of remittances exceeds the real growth rate of GDP, then their weighted average - the real growth rate of GDP plus remittances, which represents the growth of the country's ability to repay its debt-will also exceed the real growth rate of GDP. Hence, less fiscal effort will be needed

\footnotetext{
${ }^{7}$ The weight on the real growth rate of remittances is last period's share of remittances in GDP plus remittances, whereas the weight on real GDP growth is one minus that share.
} 
to either stabilize or reduce the more accurate measure of the debt ratio (debt-to-GDP plus remittances) than that required to stabilize or reduce the less accurate measure (debt-toGDP). In other words, a remittance-dependent economy that uses GDP to measure its ability to repay debt may overestimate the fiscal adjustment needed to make debt sustainable.

The opposite is true when the real growth rate of remittances is less than the real growth rate of GDP - or equivalently, the real growth rate of GDP plus remittances is less than that of GDP. In this case, the primary surplus-to-GDP ratio that stabilizes the debt-to-GDP plus remittances ratio will now be greater than the primary surplus-to-GDP ratio that stabilizes the debt-to-GDP ratio; and the primary surplus-to-GDP ratio that reduces debt-to-GDP plus remittances by a given percentage will also be greater than the primary surplus-to-GDP ratio that reduces the debt-to-GDP ratio by the same percentage. This situation may arise, for example, due to a sharp drop in the real growth rate of the remittance-sending country-a scenario currently being faced by most developed countries during the current global turmoil and following the onset of the sub-prime crisis in 2007. This lowers the real growth rate of remittances, and hence, dampens the remittance-receiving country's ability to repay its debt, which, in this case, grows slower than GDP. This implies that a remittance-dependent economy that uses GDP as its measure of the ability to repay debt may now underestimate the amount of fiscal adjustment needed to make debt sustainable.

These results indicate that understanding debt sustainability in the presence of remittances is not simply driven by dividing debt by a "larger number" (i.e., GDP plus remittances). Here, the key question to ask is whether it is the growth rate or the level of the denominator that drives the results. While it is true that accounting for remittances will likely reduce the debt burden in terms of levels, it is also true that actual debt-related crises in emerging markets have resulted at many different thresholds making identification difficult through levels. The additional restrictions on the growth rate of GDP plus remittances and its consequences for the path of the debt ratio are essential to derive our implications. We next consider the case of Lebanon to further illustrate the implication of remittances on debt sustainability.

\section{An Application: Lebanon}

Gross remittance inflows to Lebanon amounted to an estimated 20 percent of GDP in 2008, making the country one of the largest recipients of remittances as a share of GDP in the world. About 54 percent of these inflows originate in the Gulf Cooperation Council (GCC), and some 16 percent come from Lebanese working in the United States, Canada, and Australia (IMF, 2009).

Lebanon's public debt-to-GDP ratio is also one of the largest in the world. Central government gross debt was about 150 percent of GDP in 2000. It has grown to 162.5 percent of GDP in 2008, but is projected to decline over the medium term from 161.9 percent of GDP in 2009 to about 136.4 percent of GDP in 2014, through the phased implementation of the Paris III fiscal consolidation measures, together with further privatization and pledged donor support. These historical numbers and projections, also reported in Table 1 and Figure 1, are taken from the March 2009 Article IV Staff report on Lebanon (IMF, 2009). 
In Table 1 and Figure 1, we show the historical path of the debt-to-GDP plus remittances ratio since 2000. Over the period 2001-2008, the primary balance-to-GDP ratio that stabilizes the debt-to-GDP ratio is larger than that required to stabilize the debt-to-GDP plus remittances ratio. This is because over that period the real growth rate of remittances exceeded that of real GDP - or equivalently, the real growth rate of GDP plus remittances exceeded the real growth rate of GDP. Exceptions are in 2005, 2007, and 2008, where the real growth rate of remittances was less than that of real GDP (Table 1 and Figure 2).

We also assessed possible implications for fiscal adjustment over the period 2009-2014 under alternative scenarios. Underlying each scenario is the assumption that the slowdown in global economic activity and lower global liquidity, especially in the GCC, is expected to negatively affect Lebanon in 2009 through lower tourism receipts, FDI, portfolio investment, and deposit inflows. As a result, real GDP growth is projected to fall to 3 percent in 2009 from a robust 8.5 percent in 2008. Given these assumptions, three alternative scenarios for remittances are considered:

- The first scenario assumes a 6 percent real growth rate of remittances over the projection period. This is roughly the average annual real growth rate of remittances in Lebanon over the period 2000-2008. ${ }^{8}$ By allowing remittances to continue to grow at their historical average rate, this scenario implicitly assumes that remittances are resilient to the current financial crisis and the global slowdown in economic activity.

- The second scenario accounts for the empirical evidence that suggests remittance inflows are positively related to the growth rate of the remittance-sending-countries (see Chami et al. (2008) and the references therein). In the case of Lebanon, this means the projected decline in the real GDP growth rates in the GCC, United States, Canada, and Australia in 2009 is likely to lead to a sizable fall in remittance flows into Lebanon. IMF (2009) uses this empirical evidence as a basis to project a 15.9 percent drop in real remittances in 2009, which is used in this scenario. For the rest of the projection period, the real growth rate of remittances is set conservatively at zero implying a delayed or sluggish recovery in the remittance-sending countries over the medium term.

- The third scenario also sets real remittance growth at -15.9 percent for 2009 , but relies on a rebound in remittance-sending countries thereafter. Thus, it assumes a more favorable outlook for the remittance-sending countries over the period 20102014 relative to the second scenario, with real growth rates of remittances ranging between 4.2 percent and 6 percent over that period.

\footnotetext{
${ }^{8}$ Note that the remittance flows to Lebanon show considerable fluctuations, which may be a function of data limitations. Chami et al. (2008) and World Bank (2006), among others, show that remittance flows to developing countries are relatively stable over time and display much less variability than other balance of payments flows on average, including public sector transfers such as official aid.
} 
Results from estimating the fiscal adjustment for the period 2009-2014 under the alternative scenarios and debt ratio targets outlined above are displayed in Figures 1 and 2, and Table 1. The primary surpluses needed to stabilize the targeted debt ratio are reported in terms of GDP, not GDP plus remittances. This is done to permit an accurate comparison of fiscal adjustment across each scenario, regardless of whether the policy goal is to stabilize the traditional debt-to-GDP measure or debt-to-GDP plus remittances.

\section{A. Stabilizing the Debt at Current Levels}

To withstand the impact of the global crisis in the near term, and to reduce fiscal vulnerability and safeguard the recent progress in debt reduction, the authorities may be interested in stabilizing the traditional debt-to-GDP ratio in 2009 at its 2008 value of 162.5 percent. As shown in Table 1, a primary deficit of about 0.2 percent of GDP would achieve this objective. However, targeting the debt-to-GDP ratio excludes the substantial expected decline in remittances in 2009-by 15.9 percent under scenarios 2 and 3-which would reduce the amount of potential resources Lebanon has to repay its debt. Stabilizing the debtto-GDP plus remittances ratio will require greater fiscal restraint: a primary surplus of 4.8 percent of GDP under scenarios 2 and 3. If remittances are resilient to the crisis as assumed under scenario 1, they would provide a buffer for the economy. The fiscal adjustment required to stabilize the debt-to-GDP plus remittances ratio is a primary deficit of 0.9 percent of GDP, meaning the authorities could exert a smaller fiscal effort to stabilize the debt-toGDP plus remittances ratio than that needed to stabilize the debt-to-GDP ratio.

Over the period 2010-2014, projections for Lebanon's real GDP growth rate from IMF(2009) range between 4 percent and 4.5 percent, which are below the real growth rate of remittances assumed under the first and third scenarios. ${ }^{9}$ In this case, the primary surplus-to-GDP ratio that stabilizes debt-to-GDP plus remittances is less than that required to stabilize the debt-toGDP ratio. ${ }^{10}$ However, under the second scenario, the reverse is true. This is because over the period 2010-2014, the real growth rate of remittances is less than that of real GDP.

\section{B. Targeting a Lower Debt Level}

We next conduct a separate exercise where we estimate the primary balance required to reduce the debt ratio to a given target. In particular, we examine the amount of fiscal adjustment needed to reduce the debt ratio by 30 percent in 2014 relative to the level recorded in 2008. Results are reported in Table 2. An average primary surplus of 7.2 percent of GDP is required to reduce the debt-to-GDP ratio by 30 percent in 2014, while a primary surplus of only 6.9 percent of GDP is needed to reduce the debt-to-GDP plus remittances ratio under the first scenario. Since the average historical growth rate of remittances is higher

\footnotetext{
${ }^{9}$ An exception is 2013 under the third scenario. The real growth rate of remittances in 2013 (4.2 percent) is slightly less than that of real GDP (4.5 percent). In this case, the primary surplus-to-GDP ratio that stabilizes the debt-to-GDP plus remittances ratio ( 2.8 percent) is greater than that required to stabilize the debt-to-GDP ratio (2.7 percent).

${ }^{10}$ In 2010, the primary surplus-to-GDP ratio that stabilizes the debt-to-GDP ratio at its 2009 value is -12.4 percent. This number is relatively large as it reflects large privatization amounts in 2010 . However, excluding privatization amounts, the debt stabilizing primary surplus is 3.8 percent of GDP in 2010.
} 
than the assumed growth rate of real GDP over the projection period, the authorities may implement a tighter fiscal adjustment than necessary to reach the debt target if the role of remittances is overlooked.

However, if the second scenario materializes, then real remittance growth falls below real GDP growth over the projection period, meaning the primary surplus-to-GDP ratio that reduces the debt-to-GDP plus remittances ratio by 30 percent will exceed that required to reduce the debt-to-GDP ratio by the same percentage. Intuitively, GDP plus remittances is growing at a slower rate than GDP and by relying on GDP as a proxy of Lebanon's ability to repay debt rather than GDP plus remittances, the authorities may underestimate the primary surplus they need to reduce debt to a given target. The cumulative understatement (relative to the second scenario) is 6.1 percent of GDP over the period 2009-2014.

Under the third scenario, a primary surplus of 7.7 percent of GDP reduces the debt-to-GDP plus remittances ratio by 30 percent. Hence, an average primary surplus of 7.2 percent of GDP per year - the effort required to reduce the debt-to-GDP ratio by the same percentagemay not be enough to ensure stability at the lower targeted level. The projected negative impact of the crisis on remittance growth (particularly in 2009) is large enough that an additional cumulative fiscal adjustment of about 3 percent of GDP will be needed to achieve that objective.

It is also interesting to compare the third scenario with the first two. The third scenario has a more favorable outlook for remittance growth than the second scenario but a less favorable outlook than the first scenario. It is not surprising then that the amount of fiscal adjustment required to reduce the debt-to-GDP plus remittances ratio by 30 percent in the third scenario is less than the amount of fiscal adjustment in the second scenario but more than that in the first scenario.

\section{CONCLUSION}

In this paper we investigate the impact of remittances on the sustainability of government debt. We detail the conditions under which remittances can be viewed as part of the potential tax base and how the traditional debt-to-GDP ratio can be modified to create a more accurate representation of debt sustainability for a country that receives significant remittance inflows. The main result is that the inclusion of remittances in the traditional debt sustainability analysis alters the amount of fiscal adjustment required to place debt on a sustainable path, with the relative growth rate of real remittances and real GDP as the deciding factor in setting fiscal policy. While these findings should be viewed as preliminary, we believe they are illustrative of why countries with different balance of payments characteristics may be justified in constructing alternative measures of debt sustainability. In particular, remittancedependent countries may need to view stability through several metrics, using both debt-toGDP and debt-to-GDP plus remittances, for example, when evaluating the appropriate stance of fiscal policy.

Understanding the effects of remittances on the setting of fiscal policy and debt sustainability is likely to remain an important topic in the coming years. Globalization, the trend toward deeper economic integration through regional arrangements such as the Association of 
Southeast Asian Nations (ASEAN) and the European Union (EU), along with the proliferation of trade agreements like the North American Free Trade Agreement (NAFTA), have all increased flexibility in labor migration and underpinned global remittance flows. Hence, a full understanding of the characteristics of remittances and how they differ from other balance of payments flows is essential in understanding debt sustainability and economic performance more broadly. We hope this research is a step in this direction. 


\section{Figure 1. Lebanon: Debt Dynamics}

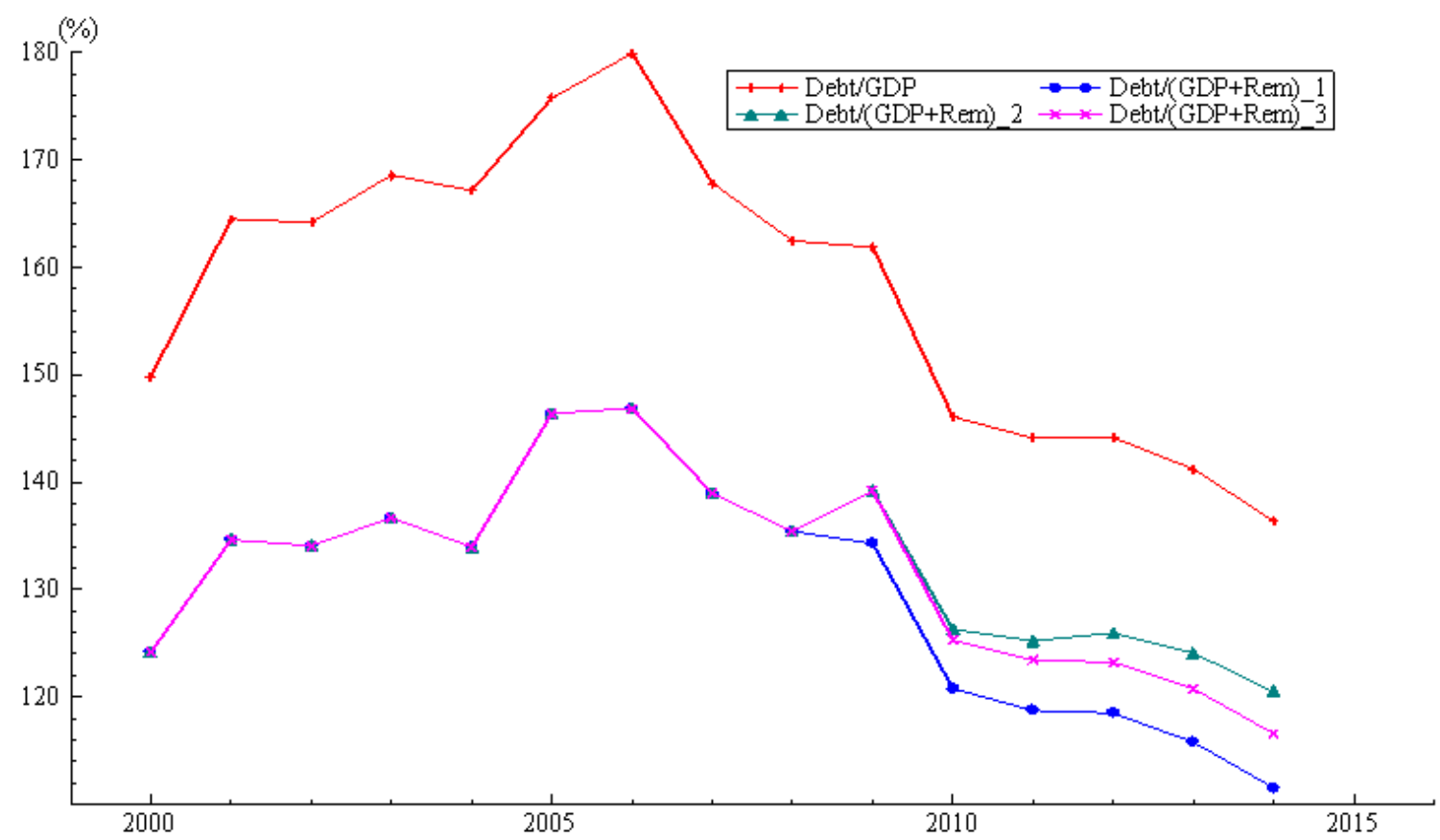

Notes: Debt/GDP is the debt-to-GDP ratio. Debt/(GDP+Rem)_1 is the debt-to-GDP plus remittances ratio under scenario 1 , which assumes a $6 \%$ real growth rate of remittances over the projection period 2009-2014. Debt/(GDP+Rem)_2 is the debt-to-GDP plus remittances ratio under scenario 2, which assumes a $-15.9 \%$ real growth rate of remittances in 2009 , and no real remittance growth thereafter. Debt/(GDP+Rem)_3 is the debt-to-GDP plus remittances ratio under scenario 3, which assumes a $15.9 \%$ real growth rate of remittances in 2009 , but positive real growth rates thereafter. Specifically, for the period 2010-2014, real remittance growth is assumed to be $5.9 \%, 4.9 \%, 6.0 \%, 4.2 \%$, and $4.7 \%$ respectively. 
Figure 2. Lebanon: Primary Surpluses that Stabilize the Debt Ratio

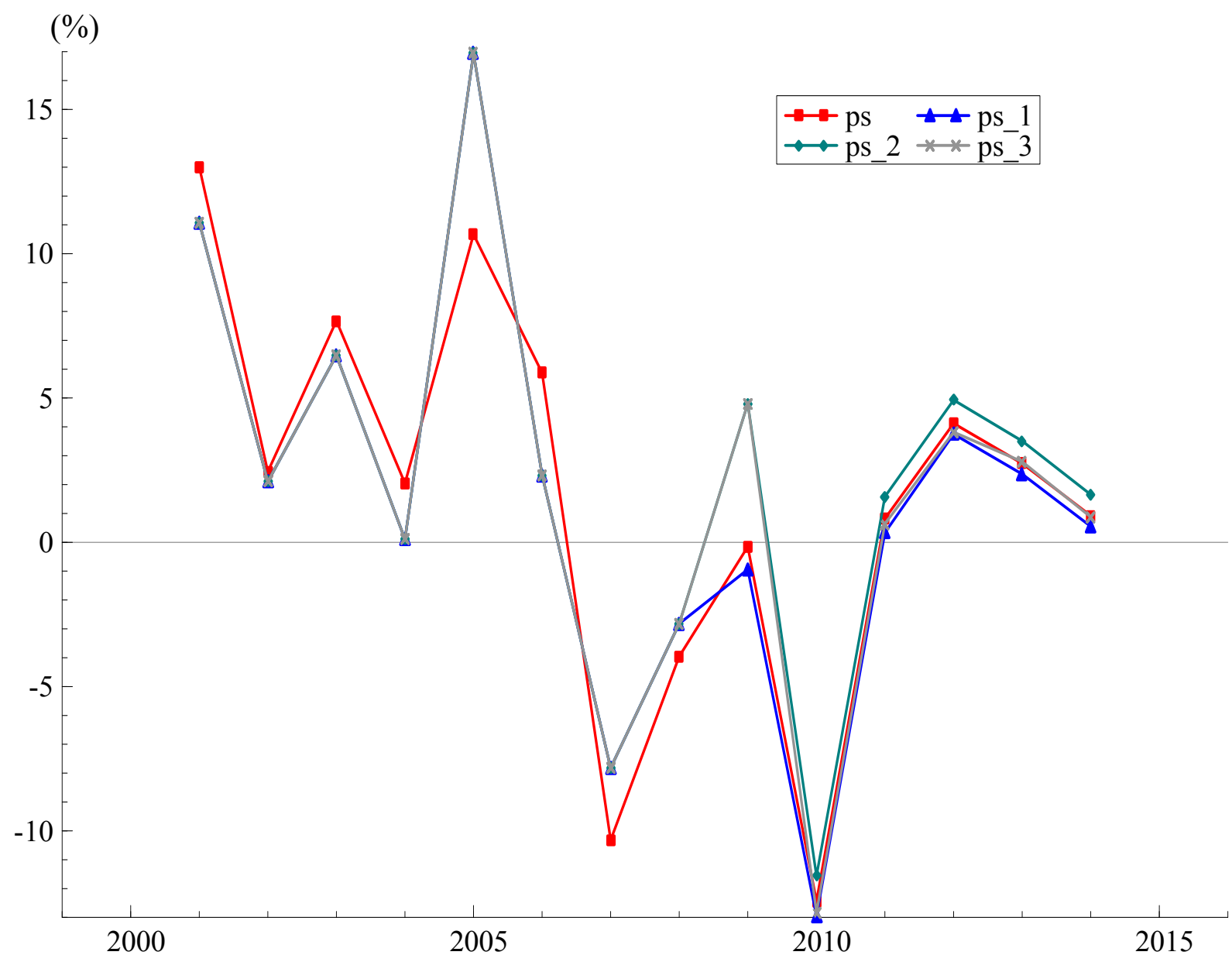

Notes: ps is the primary surplus-to-GDP ratio that stabilizes the debt-to-GDP ratio at its previous value. ps_1 is the primary surplus-to-GDP ratio that stabilizes Debt/(GDP+Rem)_1.ps_2 is the primary surplus-to-GDP ratio that stabilizes Debt/(GDP+Rem)_2. Finally, ps_3 is the primary surplusto-GDP ratio that stabilizes Debt/(GDP+Rem)_3. For definitions of the debt-to-GDP plus remittances ratios, see notes to Figure 1. 
Table 1. Debt Dynamics and Primary Surpluses that Stabilize the Debt Ratio for Lebanon

(in percent)

\begin{tabular}{|c|c|c|c|c|c|c|c|c|c|c|c|c|c|c|c|}
\hline & \multirow[b]{2}{*}{2000} & \multirow[b]{2}{*}{2001} & \multirow[b]{2}{*}{2002} & \multirow[b]{2}{*}{2003} & \multirow[b]{2}{*}{2004} & \multirow[b]{2}{*}{2005} & \multirow[b]{2}{*}{2006} & \multirow[b]{2}{*}{2007} & \multirow[b]{2}{*}{2008} & \multicolumn{6}{|c|}{ Projections } \\
\hline & & & & & & & & & & 2009 & 2010 & 2011 & 2012 & 2013 & 2014 \\
\hline Debt/GDP & 149.8 & 164.5 & 164.2 & 168.6 & 167.1 & 175.7 & 179.9 & 167.8 & 162.5 & 161.9 & 146.1 & 144.1 & 144.1 & 141.2 & 136.4 \\
\hline Debt/(GDP+Rem)_1 & 124.2 & 134.6 & 134.1 & 136.7 & 134.0 & 146.4 & 146.9 & 139.0 & 135.4 & 134.3 & 120.8 & 118.7 & 118.5 & 115.8 & 111.5 \\
\hline Debt/(GDP+Rem)_2 & 124.2 & 134.6 & 134.1 & 136.7 & 134.0 & 146.4 & 146.9 & 139.0 & 135.4 & 139.2 & 126.3 & 125.2 & 126.0 & 124.1 & 120.5 \\
\hline Debt/(GDP+Rem)_3 & 124.2 & 134.6 & 134.1 & 136.7 & 134.0 & 146.4 & 146.9 & 139.0 & 135.4 & 139.2 & 125.3 & 123.4 & 123.2 & 120.8 & 116.6 \\
\hline \multicolumn{16}{|l|}{ Primary Surplus/GDP that stabilizes: } \\
\hline Debt/GDP at its previous value & & 13.0 & 2.4 & 7.7 & 2.0 & 10.7 & 5.9 & -10.3 & -4.0 & -0.2 & -12.4 & 0.8 & 4.1 & 2.7 & 0.9 \\
\hline Debt/(GDP+Rem)_1 at its previous value & & 11.1 & 2.1 & 6.5 & 0.1 & 17.0 & 2.3 & -7.8 & -2.8 & -0.9 & -13.0 & 0.3 & 3.8 & 2.4 & 0.6 \\
\hline Debt/(GDP+Rem)_2 at its previous value & & 11.1 & 2.1 & 6.5 & 0.1 & 17.0 & 2.3 & -7.8 & -2.8 & 4.8 & -11.6 & 1.6 & 4.9 & 3.5 & 1.7 \\
\hline $\begin{array}{l}\text { Debt/(GDP+Rem }) 3 \text { at its previous value } \\
\text { Real remittance growth projections }\end{array}$ & & 11.1 & 2.1 & 6.5 & 0.1 & 17.0 & 2.3 & -7.8 & -2.8 & 4.8 & -12.8 & 0.6 & 3.8 & 2.8 & 0.87 \\
\hline Scenario 1 & & & & & & & & & & 6.0 & 6.0 & 6.0 & 6.0 & 6.0 & 6.0 \\
\hline Scenario 2 & & & & & & & & & & -15.9 & 0.0 & 0.0 & 0.0 & 0.0 & 0.0 \\
\hline Scenario 3 & & & & & & & & & & -15.9 & 5.9 & 4.9 & 6.0 & 4.2 & 4.7 \\
\hline Real GDP growth projections & & & & & & & & & & 3.0 & 4.0 & 4.0 & 4.5 & 4.5 & 4.5 \\
\hline
\end{tabular}

Notes: Debt/(GDP+Rem)_1 is the debt-to-GDP plus remittances under scenario 1. Debt/(GDP+Rem)_2 is the debt-to-GDP plus remittances under scenario 2. Debt/(GDP+Rem)_3 is the debt-to-GDP plus remittances under scenario 3. The scenarios differ only in terms of their projections of the real growth rate of remittances, also shown in the table. 
Table 2. Primary Surplus Required to Reduce the Debt Ratio to a Given Target (in percent)

\begin{tabular}{|c|c|c|c|c|c|c|c|}
\hline & 2008 & 2009 & 2010 & 2011 & 2012 & 2013 & 2014 \\
\hline Debt/GDP & 162.5 & 155.1 & 135.3 & 128.6 & 125.0 & 120.2 & 113.7 \\
\hline Primary Surplus/GDP required to reduce Debt/GDP by $30 \%$ & & 7.2 & 7.2 & 7.2 & 7.2 & 7.2 & 7.2 \\
\hline Debt/(GDP+Rem)_1 & 135.4 & 129.0 & 112.5 & 106.9 & 104.0 & 100.1 & 94.8 \\
\hline Primary Surplus/GDP required to reduce Debt/(GDP+Rem)_1 by $30 \%$ & & 6.8 & 6.9 & 6.9 & 6.9 & 6.9 & 6.9 \\
\hline Debt/(GDP+Rem)_2 & 135.4 & 132.4 & 115.0 & 108.8 & 105.4 & 100.8 & 94.8 \\
\hline Primary Surplus/GDP required to reduce Debt/(GDP+Rem)_2 by $30 \%$ & & 8.4 & 8.3 & 8.3 & 8.2 & 8.2 & 8.1 \\
\hline Debt/(GDP+Rem)_3 & 135.4 & 133.0 & 115.2 & 109.0 & 105.3 & 100.7 & 94.8 \\
\hline Primary Surplus/GDP required to reduce Debt/(GDP+Rem)_3 by $30 \%$ & & 7.7 & 7.7 & 7.7 & 7.7 & 7.7 & 7.7 \\
\hline
\end{tabular}

Notes: The table shows the primary surplus-to-GDP ratio required to reduce the debt-to-GDP ratio by $30 \%$ in 2014 relative to its value in 2008 . It also shows the primary surplus-to-GDP ratio required to reduce the debt-to-GDP plus remittances ratio by $30 \%$ in 2014 relative to its value in 2008 , under three alternative scenarios (See notes for Table 1). The corresponding paths of the debt ratios are also shown. In these calculations, it is assumed that the primary surplus-to-GDP ratio that reduces the debt-to-GDP ratio by $30 \%$ is constant over the period 2009-2014. That is, the amount of fiscal adjustment is divided evenly across time. This is done purely for simplicity. Of course, it is likely that the needed adjustment may actually be more frontloaded or less evenly divided. Similarly, we assume that, for any given scenario, the primary surplus-to-GDP plus remittances ratio required to reduce the debt-to-GDP plus remittances ratio by $30 \%$ in 2014 relative to its value in 2008 is constant over time. Note that this does not necessarily imply that the primary surplus-to-GDP ratio that achieves this objective is constant over time. 


\section{APPENDIX}

\section{Traditional Model of Debt Sustainability}

We start with the simplest possible model of debt sustainability. We assume that the government finances its deficit only by issuing debt. Hence, other financing items, such as seigniorage, privatization proceeds, and the sale of liquid assets are all set to zero [The application on Lebanon in the main text actually allows for such items]. We also abstract from issues related to debt composition (foreign currency vs. domestic currency denominated debt) as well as exchange rate movements and their impact on debt dynamics. This is done purely for simplicity. The results of the paper are robust to relaxing these simplifications.

\section{A. The law of motion of the government debt-to-GDP ratio}

Let $\mathrm{D}_{\mathrm{t}}$ denote the stock of government debt at the end of year $t, i_{t}$ the nominal interest rate, and $\mathrm{PS}_{\mathrm{t}}$ the primary surplus ( revenues minus non-interest expenditures). The government budget constraint is then given by:

$$
D_{t}=\left(1+i_{t}\right) D_{t-1}-P S_{t}
$$

Equation (1) simply states that the government will finance its overall deficit by issuing debt. Also, any primary surplus ( PS $>0$ ) in excess of the interest payments on government debt can be used to reduce the stock of existing debt.

It is useful to normalize the quantities in equation (1) by some measure of the country's ability to service and repay its debt. The most common choice is typically GDP. Dividing both sides of equation (1) by (nominal) GDP yields:

$$
\begin{aligned}
\frac{D_{t}}{G D P_{t}} & =\frac{\left(1+i_{t}\right) D_{t-1}}{G D P_{t}}-\frac{P S_{t}}{G D P_{t}} \\
& =\frac{\left(1+r_{t}\right)\left(1+\pi_{t}\right)}{\left(1+g_{t}\right)\left(1+\pi_{t}\right)} \frac{D_{t-1}}{G D P_{t-1}}-\frac{P S_{t}}{G D P_{t}}
\end{aligned}
$$

where $r_{t}$ is the real interest rate, $g_{t}$ is the real growth rate of GDP, and $\pi_{t}$ is the inflation rate (measured as the growth rate of the GDP deflator).

Using lowercase symbols to denote ratios to GDP, equation (2) can be written as:

$$
d_{t}=\left[\frac{1+r_{t}}{1+g_{t}}\right] d_{t-1}-p s_{t}
$$


Subtracting $d_{t-1}$ from both sides yields:

$$
\Delta d_{t}=\left[\frac{r_{t}-g_{t}}{1+g_{t}}\right] d_{t-1}-p s_{t}
$$

The path of $d_{t}$ will critically depend on the relationship between the real interest rate and the real growth rate of GDP. If the former is greater than the latter, then primary deficits will result in a continuous rise in the debt-to-GDP ratio, rendering it unsustainable. To prevent that from happening, the government needs to run large enough primary surpluses.

\section{B. The primary surplus-to-GDP ratio that stabilizes the debt-to-GDP ratio}

The required primary surplus-to-GDP ratio that would stabilize the debt-to-GDP ratio ( $\mathrm{ps}^{*}$ ) can be obtained by setting $\Delta \mathrm{d}_{\mathrm{t}}=0$ in equation (4):

$$
p s_{t}^{*}=\left[\frac{r_{t}-g_{t}}{1+g_{t}}\right] d_{t-1}
$$

The debt stabilizing primary surplus is increasing in the real interest rate and the debt-toGDP ratio, but decreasing in the real growth rate of GDP.

\section{The primary surplus-to-GDP ratio that reduces debt-to-GDP to a given target}

Equation (3) can be written as :

$$
d_{t}=\beta_{t} d_{t-1}-p s_{t}
$$

where $\beta_{t}=\left(1+r_{t}\right) /\left(1+g_{t}\right)$. Solving for $d_{t-1}$ yields:

$$
d_{t-1}=\beta_{t}^{-1} d_{t}+\beta_{t}^{-1} p s_{t}
$$

Equation (7) is a forward looking difference equation that holds for any two adjacent periods. Hence,

$$
d_{t}=\beta_{t+1}^{-1} d_{t+1}+\beta_{t+1}^{-1} p s_{t+1}
$$


Iterating equation (8) forward up to period $\mathrm{N}$ yields:

$$
d_{t}=\left[\prod_{i=1}^{N} \beta_{t+i}^{-1}\right] d_{t+N}+\sum_{i=1}^{N}\left[\prod_{k=1}^{i} \beta_{t+k}^{-1}\right] p s_{t+i}
$$

If the current level of the debt-to-GDP ratio is deemed to be too high, the authorities may be interested in calculating the primary surplus-to-GDP ratio that would reduce the debt-to-GDP ratio to a given target in period $\mathrm{t}+\mathrm{N}$. Let $\mathrm{d}_{\mathrm{t}+\mathrm{N}}=\gamma^{*} \mathrm{~d}_{\mathrm{t}}$ be the target debt-to-GDP ratio in period $\mathrm{t}+\mathrm{N}$, where $0<\gamma^{*} \leq 1$. Also assume, for simplicity, that the sequence $\left(\mathrm{ps}_{\mathrm{t}+1}, \mathrm{ps}_{\mathrm{t}+2}, \ldots, \mathrm{ps}_{\mathrm{t}+\mathrm{N}}\right)$ that reduces $\mathrm{d}_{\mathrm{t}}$ to $\mathrm{d}_{\mathrm{t}+\mathrm{N}}$ is such that $\mathrm{ps}_{\mathrm{t}+1}=\mathrm{ps}_{\mathrm{t}+2}=\ldots=\mathrm{ps}_{\mathrm{t}+\mathrm{N}}$. Equation (9) then implies that the $\operatorname{ps}_{t+j}(j=1,2, \ldots N)$ that would reduce $d_{t}$ to its target $d_{t+N}=\gamma^{*} d_{t}$ is given by:

$$
p s_{t+j}=\frac{1-\left(\prod_{i=1}^{N} \beta_{t+i}^{-1}\right) \gamma^{*}}{\sum_{i=1}^{N}\left(\prod_{k=1}^{i} \beta_{t+k}^{-1}\right)} d_{t} \quad j=1,2, \ldots N
$$

The primary surplus-to-GDP ratio that would reduce the debt-to-GDP ratio to a given target increases with the real interest rate but decreases with the real growth rate of GDP [ recall $\beta_{\mathrm{t}}$ $\left.=\left(1+r_{t}\right) /\left(1+g_{t}\right)\right]$. It also varies positively with the current debt-to-GDP ratio, but negatively with $\gamma^{*}$ and the length of the adjustment period N. Intuitively, a smaller current debt-to-GDP ratio and a larger $\gamma^{*}$ imply that the gap between the current debt-to-GDP ratio and the target is smaller, requiring less cumulative and hence annual effort on the part of the government. Also, a larger $\mathrm{N}$ smoothens the adjustment process requiring less primary surplus per year to close the gap between the current debt-to-GDP ratio and the target.

\section{Debt Sustainability in the Presence of Remittances}

To assess debt sustainability, we usually normalize debt by some measure of the country's ability to repay its debt - typically GDP. However, for a country that receives significant remittance flows, a more accurate measure of that country's ability to repay its debt would be GDP plus remittances. Hence, for such a country, normalizing debt by GDP plus remittances will give a more accurate metric/measure of debt sustainability. 


\section{A. The law of motion of the government debt-to-GDP plus remittances ratio}

Dividing both sides of equation (1) by GDP plus remittances yields:

$$
\begin{aligned}
\frac{D_{t}}{G D P_{t}+\operatorname{Re} m_{t}} & =\frac{\left(1+i_{t}\right) D_{t-1}}{G D P_{t}+\operatorname{Re} m_{t}}-\frac{P S_{t}}{G D P_{t}+\operatorname{Re} m_{t}} \\
& =\frac{\left(1+r_{t}\right)\left(1+\pi_{t}\right)}{\left[1+g_{t}+s_{t-1}\left(\rho_{t}-g_{t}\right)\right]\left(1+\pi_{t}\right)} \frac{D_{t-1}}{G D P_{t-1}+\operatorname{Re} m_{t-1}}-\frac{P S_{t}}{G D P_{t}+\operatorname{Re} m_{t}} \\
& =\frac{\left(1+r_{t}\right)}{\left[1+g_{t}+s_{t-1}\left(\rho_{t}-g_{t}\right)\right]} \frac{D_{t-1}}{G D P_{t-1}+\operatorname{Re} m_{t-1}}-\frac{P S_{t}}{G D P_{t}+\operatorname{Re} m_{t}}
\end{aligned}
$$

where Rem $_{t}$ denotes (nominal) remittances, $\rho_{t}$ the real growth rate of remittances, and $s_{t-1}$ the share of remittances in GDP plus remittances in the previous period.

Let $\hat{d}_{t}=D_{t} /\left(G D P_{t}+\operatorname{Re} m_{t}\right)$, and $p s_{t}=P S_{t} /\left(G D P_{t}+\operatorname{Re} m_{t}\right)$, then equation (11) can be written as:

$$
\left.\hat{d}_{t}=\frac{\left(1+r_{t}\right)}{\left[1+g_{t}+s_{t-1}\left(\rho_{t}-g_{t}\right)\right]} \hat{d}_{t-1}-p s_{t}\right)
$$

Subtracting $\hat{d}_{t-1}$ from both sides yields:

$$
\Delta \hat{d}_{t}=\frac{r_{t}-\left[g_{t}+s_{t-1}\left(\rho_{t}-g_{t}\right)\right]}{1+\left[g_{t}+s_{t-1}\left(\rho_{t}-g_{t}\right)\right]} \hat{d}_{t-1}-p s_{t}
$$

Several interesting observations emerge from equation (13). First, in a world with no remittances (i.e. $\mathrm{s}_{\mathrm{t}-1}=0$ ), equation (13) will be reduced to the traditional model of debt sustainability (equation 4). Second, sustainability in the presence of remittances will no longer depend on the relationship between the real interest rate and the real growth rate of GDP, but rather on the relationship between the real interest rate and the real growth rate of GDP plus remittances. The latter is a weighted average of the real growth rate of GDP and the real growth rate of remittances - the term in square brackets in equation (13). Finally, A larger real growth rate of remittances will enhance the country's ability to repay its debt, increase the real growth rate of GDP plus remittances, and hence will improve debt sustainability. 


\section{B. The primary surplus-to-GDP ratio that stabilizes debt-to-GDP plus remittances}

In this sub-section, we derive an expression for the primary surplus-to-GDP ratio that stabilizes debt-to-GDP plus remittances. We compare this expression with the primary surplus-to-GDP ratio that stabilizes the debt-to-GDP ratio, as derived in section I.B.

Setting $\Delta \hat{d}_{t}=0$ in equation (13) yields:

$$
p s_{t}^{*}=\frac{r_{t}-\left[g_{t}+s_{t-1}\left(\rho_{t}-g_{t}\right)\right]}{1+\left[g_{t}+s_{t-1}\left(\rho_{t}-g_{t}\right)\right]} \hat{d}_{t-1}
$$

Let $\overline{p s}{ }_{t}$ denote the primary surplus-to-GDP ratio that makes $\Delta \hat{d}_{t}=0$. Multiplying both sides of equation (14) by $\left(G D P_{t}+\operatorname{Rem}_{t}\right) / G D P_{t}$ yields the following expression for $\overline{p s_{t}}$ :

$$
\begin{aligned}
& \overline{p s_{t}}=\frac{r_{t}-\left[g_{t}+s_{t-1}\left(\rho_{t}-g_{t}\right)\right]}{1+\left[g_{t}+s_{t-1}\left(\rho_{t}-g_{t}\right)\right]} \hat{d}_{t-1} \frac{G D P_{t}+\operatorname{Rem}_{t}}{G D P_{t}} \\
& =\frac{r_{t}-\left[g_{t}+s_{t-1}\left(\rho_{t}-g_{t}\right)\right]}{1+\left[g_{t}+s_{t-1}\left(\rho_{t}-g_{t}\right)\right]} \hat{d}_{t-1} \frac{\left[1+g_{t}+s_{t-1}\left(\rho_{t}-g_{t}\right)\right]\left(1+\pi_{t}\right)}{\left(1+g_{t}\right)\left(1+\pi_{t}\right)} \quad \frac{G D P_{t-1}+\operatorname{Rem}_{t-1}}{G D P_{t-1}}
\end{aligned}
$$

The above expression simplifies to:

$$
\overline{p s_{t}}=\frac{r_{t}-\left[g_{t}+s_{t-1}\left(\rho_{t}-g_{t}\right)\right]}{1+g_{t}} d_{t-1}
$$

Equation (16) implies that $\overline{p s_{t}}$ varies positively with the real interest rate and the debt-toGDP ratio, but negatively with the real growth of GDP plus remittances - the term in square brackets. It is interesting to compare $\overline{p s_{t}}$ with $p s_{t}^{*}$ in equation (5) - the primary surplus-to GDP ratio that stabilizes the debt- to-GDP ratio. If the real growth rate of remittances exceeds the real growth rate of GDP, then their weighted average - the real growth of GDP plus remittances - will also exceed the real growth rate of GDP. This implies that $\overline{p s_{t}}$ will be less than $p s_{t}^{*}$. In this case, the country's ability to repay its debt is growing faster than GDP, requiring less effort to stabilize the debt-to-GDP plus remittances ratio than that required to stabilize the debt-to-GDP ratio. Stated differently, in a country where remittances 
are growing faster than GDP, an effort equal to $\overline{p s_{t}}$ would actually cause the debt-to-GDP ratio to rise but will stabilize the more accurate measure of debt sustainability $\hat{d}_{t}$.

On the other hand, if the real growth rate of remittances is less than the real growth rate of GDP, then their weighted average - the real growth of GDP plus remittances - will also be less than the real growth rate of GDP. This implies that $\overline{p s_{t}}$ will be greater than $p s_{t}^{*}$.

Intuitively, in this case, GDP overstates the country's ability to repay its debt. The more accurate measure of the ability to repay debt, GDP plus remittances, is growing at a slower rate than GDP. Hence, while an effort equal to $p s_{t}^{*}$ would stabilize the debt-to-GDP ratio, it will cause the more accurate measure of sustainability, $\hat{d}_{t}$, to rise over time. Finally, if the real growth rate of remittances is equal to the real growth rate of GDP, then the real growth of GDP plus remittances will also be equal to the real growth rate of GDP. In this case, equation (16) and equation (5) become identical, and $\overline{p s_{t}}$ will be equal to $p s_{t}^{*}$.

\section{The primary surplus-to-GDP ratio that reduces debt-to-GDP plus remittances to a given target}

In section I.C, we derived an expression for the primary surplus-to-GDP ratio that reduces the debt-to-GDP ratio by a given percentage [equation 10]. In this sub-section, we derive an expression for the primary surplus-to-GDP ratio that reduces debt-to-GDP plus remittances by the same percentage, and then compare the two expressions.

Letting $\hat{\beta}_{t}=\frac{\left(1+r_{t}\right)}{\left[1+g_{t}+s_{t-1}\left(\rho_{t}-g_{t}\right)\right]}$ and following similar steps as in section I.C, equation (12) can be written as :

$$
\hat{d}_{t}=\hat{\beta}_{t+1}^{-1} \hat{d}_{t+1}+\hat{\beta}_{t+1}^{-1} \not s_{t+1}
$$

Iterating equation (17) forward up to period $\mathrm{N}$ yields:

$$
\hat{d}_{t}=\left[\prod_{i=1}^{N} \hat{\beta}_{t+i}^{-1}\right] \hat{d}_{t+N}+\sum_{i=1}^{N}\left[\prod_{k=1}^{i} \hat{\beta}_{t+k}^{-1}\right] p s_{t+i}
$$

Suppose that the current debt-to-GDP plus remittances ratio is believed to be too high, the authorities may be interested in calculating the primary surplus-to-GDP ratio that would reduce the debt-to-GDP plus remittances ratio to a given target in period $\mathrm{t}+\mathrm{N}$. Let $\hat{d}_{t+N}=\gamma^{*} \hat{d}_{t}$ be the target debt-to-GDP plus remittances ratio in period $\mathrm{t}+\mathrm{N}$, where $0<\gamma^{*} \leq 1$. Also assume, for simplicity, that the sequence $\left(p s_{t+1}, p s_{t+2}, \ldots, p s_{t+N}\right)$ that reduces $\hat{d}_{t}$ to 
$\hat{d}_{t+N}$ is such that $p s_{t+1}=p s_{t+2}=\ldots=p s_{t+N}$. Equation (18) then implies that the $p s_{t+j}($ $\mathrm{j}=1,2, \ldots \mathrm{N})$ that would reduce $\hat{d}_{t}$ to its target $\hat{d}_{t+N}=\gamma^{*} \hat{d}_{t}$ is given by:

$$
p s_{t+j}=\frac{1-\left(\prod_{i=1}^{N} \hat{\beta}_{t+i}^{-1}\right) \gamma^{*}}{\sum_{i=1}^{N}\left(\prod_{k=1}^{i} \hat{\beta}_{t+k}^{-1}\right)} \hat{d}_{t} \quad j=1,2, \ldots N
$$

By multiplying both sides of equation (19) by $\left(G D P_{t+j}+\operatorname{Rem}_{t+j}\right) / G D P_{t+j}$, we can solve for the implied primary surplus-to-GDP ratio that would reduce $\hat{d}_{t}$ to its target $\hat{d}_{t+N}=\gamma^{*} \hat{d}_{t}$. Let $\overline{\overline{p s}}_{t+j}$ denote that ratio. Then $\overline{\overline{p s}}_{t+j}$ will be given by:

$$
\begin{aligned}
\overline{\overline{p s}}_{t+j} & =\frac{1-\left(\prod_{i=1}^{N} \hat{\beta}_{t+i}^{-1}\right) \gamma^{*}}{\sum_{i=1}^{N}\left(\prod_{k=1}^{i} \hat{\beta}_{t+k}^{-1}\right)} \hat{d}_{t} \frac{G D P_{t+j}+\operatorname{Rem}_{t+j}}{G D P_{t+j}} \\
& =\frac{1-\left(\prod_{i=1}^{N} \hat{\beta}_{t+i}^{-1}\right) \gamma^{*}}{\sum_{i=1}^{N}\left(\prod_{k=1}^{i} \hat{\beta}_{t+k}^{-1}\right)} \hat{d}_{t} \frac{G D P_{t}+\operatorname{Rem}_{t}}{G D P_{t}} \prod_{k=1}^{j} \frac{1+g_{t+k}+s_{t+k-1}\left(\rho_{t+k}-g_{t+k}\right)}{1+g_{t+k}} \\
& =\frac{1-\left(\prod_{i=1}^{N} \hat{\beta}_{t+i}^{-1}\right) \gamma^{*}}{\sum_{i=1}^{N}\left(\prod_{k=1}^{i} \hat{\beta}_{t+k}^{-1}\right)} d_{t} \prod_{k=1}^{j} \frac{1+g_{t+k}+s_{t+k-1}\left(\rho_{t+k}-g_{t+k}\right)}{1+g_{t+k}} \quad j=1,2, \ldots N
\end{aligned}
$$

Equations (20) and (10) become identical if the real growth rate of remittances is equal to the real growth rate of GDP. That is, $p s_{t+j}$ will be equal to $\overline{\overline{p s}}_{t+j}$ if $\rho_{t+i}=g_{t+i} \quad(i=1,2, \ldots, N)$. This is because the last term in equation (20) now equals unity, and $\beta$ and $\hat{\beta}$ are now identical. It can also be shown that if the real growth rate of remittances is greater (less) than the real growth rate of GDP, then $p s_{t+j}$ will be greater (less) than $\overline{\overline{p s}}_{t+j}$. To see this clearly and without loss of generality, consider the case when $\mathrm{N}=1$. That is , the length of the adjustment period is equal to unity. In this case, equations (20) and (10) are reduced to equations (21) and (22) respectively:

$$
\overline{\overline{p s}}_{t+1}=\frac{\left(1+r_{t+1}\right)-\left[1+g_{t+1}+s_{t}\left(\rho_{t+1}-g_{t+1}\right)\right] \gamma^{*}}{1+g_{t+1}} d_{t}
$$




$$
p s_{t+1}=\frac{\left(1+r_{t+1}\right)-\left(1+g_{t+1}\right) \gamma^{*}}{1+g_{t+1}} d_{t}
$$

and their difference is given by:

$$
p s_{t+1}-\overline{\overline{p s}}_{t+1}=\frac{s_{t}\left(\rho_{t+1}-g_{t+1}\right) \gamma^{*} d_{t}}{1+g_{t+1}}
$$

It is clear from the above equations that the relationship between $p s_{t+1}$ and $\overline{\overline{p s}}$ til will depend on whether the real growth rate of remittances is greater than, less than, or equal to the real growth rate of GDP. To get some intuition on these results consider, for example, the case where $\rho_{t+1}>g_{t+1}$. In this case, the real growth rate of GDP plus remittances - the more accurate measure of a country's ability to repay its debt - exceeds real GDP growth, the less accurate measure. This requires less effort to reduce the debt-to GDP plus remittances ratio (the more accurate measure of sustainability) by a given percentage than that needed to cut the debt-to-GDP ratio by the same percentage. In other words, a remittance dependent economy that wrongly relies on GDP as a proxy of its ability to repay debt will overstate the amount of primary surplus it needs to reduce its debt to a given target. On the other hand, if $\rho_{t+1}<g_{t+1}$, then real GDP growth exceeds the real growth rate of GDP plus remittances. In this case, a remittance dependent economy will understate the primary surplus it needs to reduce its debt to a given target if it relies on GDP as a measure of its ability to repay debt. Similar arguments can be made for the case where $\rho_{t+1}=g_{t+1}$. 


\section{References}

Acosta, P. A., E. Lartey, and F. Mandelman, 2007, "Remittances and the Dutch Disease", Federal Reserve Bank of Atlanta Working Paper 2007-8.

Barrajas A, R. Chami, C. Fullenkamp, M. Gapen, and P. Montiel, 2009, “Do Workers' Remittances Promote Economic Development?” IMF Working Paper 09/153 (Washington: International Monetary Fund).

Chami, R., A. Barajas, T. Cosimano, C. Fullenkamp, M. Gapen, and P. Montiel, 2008, "Macroeconomic Consequences of Remittances", IMF Occasional Paper (Washington: International Monetary Fund).

Chami, R., T.F. Cosimano, and M. Gapen, 2006, "Beware of Emigrants Bearing Gifts: Optimal Fiscal and Monetary Policy in the Presence of Remittances", IMF Working Papers 06/61 (Washington: International Monetary Fund).

Chami, R., C. Fullenkamp, and S. Jahjah, 2003, "Are Immigrant Remittance Flows a Source of Capital for Development?", IMF Working Papers 03/189 (Washington: International Monetary Fund).

Gordon, Roger and Wei Li, 2006. "Tax Structures in Developing Countries: Many Puzzles and a Possible Explanation." November.

International Monetary Fund, 2009, Lebanon: 2009 Article IV Consultation and Assessment of Performance Under the Program Supported by Emergency Post-Conflict Assistance - Staff Report (Washington: International Monetary Fund).

International Monetary Fund, 2005, World Economic Outlook, April 2005: Globalization and External Imbalances, World Economic and Financial Surveys (Washington).

Montiel, Peter J. 2006, "Workers' Remittances and the Long-Run Equilibrium Real Exchange Rate: Analytical Issues," Williams College, mimeo.

World Bank, 2006, Global Economic Prospects: Economic Implications of Remittances and Migration (Washington: The World Bank). 